\title{
Influence of socio-economic status and environmental factors on serologically diagnosed Japanese encephalitis cases in the state of West Bengal, India during 2005-2010
}

\author{
Arindam Sarkar ${ }^{1}$, Debjani Taraphdar ${ }^{1}$, Bansi B. Mukhopadhyay ${ }^{2}$, Manish Kumar ${ }^{3}$, \\ Subhra K. Mukhopadhyay ${ }^{4}$, Shyamalendu Chatterjee ${ }^{1^{\star}}$ \\ ${ }^{1}$ ICMR Virus Unit, Kolkata, India; ${ }^{*}$ Corresponding Author: shyamalenduchatterjee@gmail.com \\ ${ }^{2}$ Department of Community Medicine, KPC Medical College, Kolkata, India \\ ${ }^{3}$ Institute of Psychiatry, Institute of Post Graduate Medical Education and Research (IPGMER), Kolkata, India \\ ${ }^{4}$ Department of Microbiology, The University of Burdwan, Burdwan, India
}

Received 29 August 2011; revised 12 October 2011; accepted 5 November 2011

\section{ABSTRACT}

Objectives: The main aim of the current study is to examine the influence of socio-economic status and environmental factors on serologically diagnosed Japanese encephalitis cases in the state of West Bengal, India during 2005-2010. Materials and methods: A total of 648 blood/CSF specimens were collected and/or referred from the suspected AES cases, admitted in the different medical colleges and hospitals of the state during the year of 2005-2010. These specimens were subjected to JE Mac ELISA to determine the actual JE case amongst these AES. The association of the socio-economic status and environmental factors with the serologically diagnosed JE positive cases was studied by a statistical analysis through Normal Deviate test or Z test. Result: Out of 648 specimens, only 175 (27.0\%) specimens were reactive to JE IgM antibody, of which $60.0 \%$ were from the male individuals and $40.0 \%$ from the female population. Major cases were observed in the age group of 0 - 10 years; followed by 11 - 20 years. Regarding literacy, only $58.3 \%$ cases had no education and $41.7 \%$ were from the literate with varying level of education, i.e., from primary level to post graduate level. A total of $65.7 \%$ cases were from low income group where as only $34.3 \%$ cases were from high income group. Regarding house type, $62.3 \%$ cases lived in mud house and $37.7 \%$ cases lived in the brick house. In most of the cases $(\mathbf{7 4 . 3 \% )}$, persons were living in close proximity to rice fields/lakes/ponds. $69.7 \%$ cases were found to occur in the monsoon and post- monsoon period whereas $30.3 \%$ cases were reported in the pre-monsoon period. Conclusion: Our study concludes that socio-economic status and environmental conditions were statistically significant contextual risk factors for serologically diagnosed JE incidences in West Bengal where JE is proved to be endemic in nature and such study constitutes a new report of this kind in the region.

Keywords: Japanese Encephalitis; Socio-Economic Status; Acute Encephalitis Syndrome (AES); West Bengal

\section{INTRODUCTION}

Japanese encephalitis (JE) is a neurotrophic killer disease caused by the mosquito-borne Japanese encephalitis virus (JEV), a member of the genus flavivirus under the family flaviviridae [1]. It is a disease of major public health importance due to its high epidemic potential, high case fatality rate and neurological sequelae among survivors. Approximately 3 billion people ( $60 \%$ of the world's population) live in J.E. endemic regions [2]. The worldwide incidental scenario of JE is 30,000 - 50,000 cases per year, the estimated mortality is 10,000 per year, whereas about $30 \%$ of survivors develop serious permanent neuropsychiatric problem [3].

In a zoonotic cycle, JEV is transmitted by vector mosquitoes (Culex sp.) [4] between wild/domestic birds and pigs; where birds act as reservoir host [5] and pigs act as amplifying host [6]. Pig-mosquito-pig and bird-mosquitobird cycle is responsible for the maintenance of the virus in nature. Man is the "dead end" host $[7,8]$. 
JE was first recognized in Japan and since the isolation of this virus in Japan in 1935; it has spread all over the world including India and has become a major public health problem.

In India, the existence of JEV was first reported serologically in 1954 [9]. However, the disease was first recognized in India at Vellore in 1955 [10]. Since then, epidemics of JE in different states have been recorded [11,12]. From 1978 to 2007, 103,389 cases and 33,729 deaths due to JEV infection were recorded from various parts of India [13].

In West Bengal, the first major outbreak of JE took place in the year 1973 in the district of Burdwan and Bankura where more than 700 cases and 300 deaths have been reported [14-16]. Since then many out breaks have been reported [17-19]. Though, the vaccination programme against JE has been conducted by the State Health Department, Govt. Of West Bengal in the different districts of West Bengal, still now every year sporadic cases are continuously being reported [20], which proves the endemicity of JE in this state.

Previous reports have been suggested that Socio-economic status, demographic variables and environmental factors play an important role in the spread JE along with the population dynamics of the vector mosquitoes [21, 22].

Here, we report a five years' (2005-2010) study to correlate the influence of Socio-economic status and Environmental factors on serologically diagnosed Japanese Encephalitis cases in the state of West Bengal.

\section{MATERIALS AND METHODS}

\subsection{Study Area}

The study was under taken in the state of West Bengal, situated at the eastern part $\left(23^{\circ} 00^{\prime} \mathrm{N}, 87^{\circ} 00^{\prime} \mathrm{E}\right)$ of the India [23]. The state has an area of $88,752 \mathrm{~km}^{2}$ [24]. The population of West Bengal is 91,347,736 [25]. Vast paddy fields with 3 - 4 inches stagnant water (serves as congenial home for mosquito breeding) is the common scenario in the districts of the central and southern part of the state. The people belong to rural area of the state are economically backward. Agriculture is the main economic source and most of the people of the rural area in this state, are involved in agricultural practices. The field labours of the rural area mostly belong to the economically backward classes. To raise their economic status; they usually taken up piggery and mini-poultry in their own hut, commonly share the habitat with human population [24].

Except the northern hilly region, other part of this state is warm and humid for a maximum time of the year. Here, the main seasons are summer, monsoon, autumn, late autumn and winter. The summer lasts from mid-March to
mid-June, with the temperature ranging from $38^{\circ} \mathrm{C}$ to $45^{\circ} \mathrm{C}$. The monsoon arrives by middle of June and continues up to the month of September. The agricultural activities are at their peaks during the post-monsoon phase which persists between middle of September to the end of November of the year [26].

\subsection{Patients and Clinical Specimens}

The study group, i.e., the patients, clinically diagnosed as Acute Encephalitis Syndrome (AES), having high grade fever $\left(\geq 39^{\circ} \mathrm{C}\right)$ for $\geq 10$ days with any two of the following symptoms, viz. headache, vomiting, unconsciousness, convulsions, abnormal movements, stupor, delirium, altered sensorium, neck rigidity, presence of kernig's sign; admitted to the different medical colleges and district hospitals were considered for this study period during 2005-2010. Details of the patients were provided by the concerned clinicians of the above said respective hospitals.

Informed consents were taken in prescribed proforma from the relatives of the patients before the collection of the blood/CSF specimens. A total of $648 \mathrm{blood} / \mathrm{CSF}$ specimens $(2-5 \mathrm{ml})$ were collected and/or referred from the above said clinically suspected AES cases in sterile vacutainers or test tubes by vein puncture/lumber puncture. All the specimens were transported to the ICMR (Indian Council of Medical Research) Virus Unit, Kolkata, for the detection of IgM antibody against JEV, maintaining the cold chain using vaccine carriers. After receiving the blood/CSF specimens along with the duly filled consent forms and the particulars of the patients from the above said hospitals, serum was separated from the clotted blood and finally, both the sera and the CSF were transferred to sterile aliquots and stored at $4^{\circ} \mathrm{C}$ and/or $-80^{\circ} \mathrm{C}$ till tested. A register was maintained in which the particulars of the patients, i.e., name, age, address, financial status, residential and environmental condition along with disease character was entered.

\subsection{Specimens Testing}

For the detection of IgM antibody against JEV in the collected specimens, M antibody captured Enzyme-linked Immunosorbent (Mac ELISA) was performed using the kit that was procured from National Institute of Virology (NIV), Pune [27,28]; following the prescribed protocol. O.D was measured at $450 \mathrm{~nm}$ using an ELISA reader (Titerteck Multiskan Plus, Lab systems Finland, Type314).

\subsection{Statistical Method}

To evaluate or correlate the impact of Socio-economic status and Environmental factors on serologically diagnosed Japanese Encephalitis cases; statistical analysis 
was performed using Normal Deviate test or $\mathrm{Z}$ test. For testing the significance of proportion of incidences among the all IgM positive cases, the hypothesis followed below:

$\mathrm{H}_{0}: \mathrm{P}=0.5$ (null hypothesis)

against, $\mathrm{H}_{1}: \mathrm{P}>0.5$ (alternative hypothesis)

where, $\mathrm{P}=$ proportion of the cases in the more susceptible group in the parent population.

\section{RESULTS}

Out of 648 specimens, only 175 (27.0\%) specimens were reactive to JE IgM antibody by ELISA method, among them $105(60.0 \%)$ cases were from male individuals and $70(40.0 \%)$ cases were female population (Table 1, Figure 1). In addition, in most of the male \& female IgM positive cases, i.e., 77 out of 175 (44.0\%) belong to the $0-10$ years age group and 42 out of 175 $(24.0 \%)$ were in the age group of $11-20$ years. (Table 1 , Figure 1).

So far literacy is concerned, only $102(58.3 \%)$ out of 175 cases were from illiterate group and $73(41.7 \%)$ cases were literates having varying level of education, i.e., from primary level to post graduate level (Tables 2 and 3, Figure 2).

Table 1. Age group \& Sex wise distribution of JE IgM positive cases from the year of 2005-2010.

\begin{tabular}{|c|c|c|c|c|c|c|c|c|c|c|}
\hline \multirow{2}{*}{ Sex } & \multicolumn{6}{|c|}{ Age group (in years) } & \multirow{2}{*}{$\begin{array}{c}\text { Sub total } \\
\text { (No. of IgM + ve } \\
\text { cases) }\end{array}$} & \multirow{2}{*}{$\begin{array}{c}\text { Total } \\
\text { (No. of IgM }+ \text { ve } \\
\text { cases) }\end{array}$} & \multirow{2}{*}{$Z$ value } & \multirow{2}{*}{$P$ value } \\
\hline & $0-10$ & $11-20$ & $21-30$ & $31-40$ & $41-50$ & $>51$ & & & & \\
\hline \multirow[t]{2}{*}{ Male } & $\begin{array}{c}46 \\
(26.28 \%)\end{array}$ & $\begin{array}{c}24 \\
(13.71 \%)\end{array}$ & $\begin{array}{c}7 \\
(4.00 \%)\end{array}$ & $\begin{array}{c}8 \\
(4.57 \%)\end{array}$ & $\begin{array}{c}8 \\
(4.57 \%)\end{array}$ & $\begin{array}{c}12 \\
(6.85 \%)\end{array}$ & $105(60.00 \%)$ & & & \\
\hline & & & & & & & & 175 & 2.65 & $\mathrm{P}<0.01$ \\
\hline Female & $\begin{array}{c}31 \\
(17.71 \%)\end{array}$ & $\begin{array}{c}18 \\
(10.28 \%)\end{array}$ & $\begin{array}{c}4 \\
(2.28 \%)\end{array}$ & $\begin{array}{c}6 \\
(3.42 \%)\end{array}$ & $\begin{array}{c}4 \\
(2.28 \%)\end{array}$ & $\begin{array}{c}7 \\
(4.00 \%)\end{array}$ & $70(40.00 \%)$ & & & \\
\hline
\end{tabular}

Table 2. Distribution of JE IgM positive cases against socio-economic status and environmental factor.

\begin{tabular}{|c|c|c|c|c|c|}
\hline & Variables $(\mathrm{N}=175)$ & $\begin{array}{c}\text { No. of } \\
\text { IgM }+ \text { ve cases }\end{array}$ & $\begin{array}{c}\text { Total No. of } \\
\text { IgM }+ \text { ve cases }\end{array}$ & $Z$ value & $P$ value \\
\hline & Illiterate & $102(58.28 \%)$ & & & \\
\hline \multirow[t]{3}{*}{ Educational Status } & & & 175 & 2.19 & $\mathrm{P}<0.05$ \\
\hline & Literate & $73(41.71 \%)$ & & & \\
\hline & $\begin{array}{l}\text { Low Income Group } \\
\text { (Income } \leq \text { Rs 5000/month) }\end{array}$ & $115(65.71 \%)$ & & & \\
\hline \multirow[t]{3}{*}{ Economic Status } & & & 175 & 4.15 & $\mathrm{P}<0.01$ \\
\hline & $\begin{array}{l}\text { High Income Group } \\
\text { (Income }>\text { Rs 5000/month) }\end{array}$ & $60(34.28 \%)$ & & & \\
\hline & Mud house & $109(62.28 \%)$ & & & \\
\hline \multirow[t]{3}{*}{ House type } & & & 175 & 3.25 & $\mathrm{P}<0.01$ \\
\hline & Brick house & $66(37.71 \%)$ & & & \\
\hline & Yes & $130(74.38 \%)$ & & & \\
\hline \multirow[t]{3}{*}{$\begin{array}{l}\text { Breeding \& staging site for Mosquito/bird in } \\
\text { rice fields/lakes/ponds Near patients' house }\end{array}$} & & & 175 & 6.42 & $P=0$ \\
\hline & No & $45(25.71 \%)$ & & & \\
\hline & Pre-monsoon & $53(30.28 \%)$ & & & \\
\hline \multirow[t]{2}{*}{ Monsoon type } & & & 175 & 5.2 & $\mathrm{P}<0.00001$ \\
\hline & Post-monsoon & $122(69.71 \%)$ & & & \\
\hline
\end{tabular}

Table 3. Literacy level in respect to JE IgM positive cases from the year of 2005-2010.

\begin{tabular}{ccc}
\hline Literacy level & No. of IgM + ve JE cases & Total no. of IgM + ve JE cases in literates \\
\hline Primary & $22(30.13 \%)$ & 73 \\
Lower secondary & $28(38.38 \%)$ \\
Secondary & $14(19.17 \%)$ \\
Higher secondary & $5(6.84 \%)$ & 73 \\
Graduate & $3(4.10 \%)$ & 73 \\
Post graduate & $1(1.36 \%)$ & 73 \\
\hline
\end{tabular}




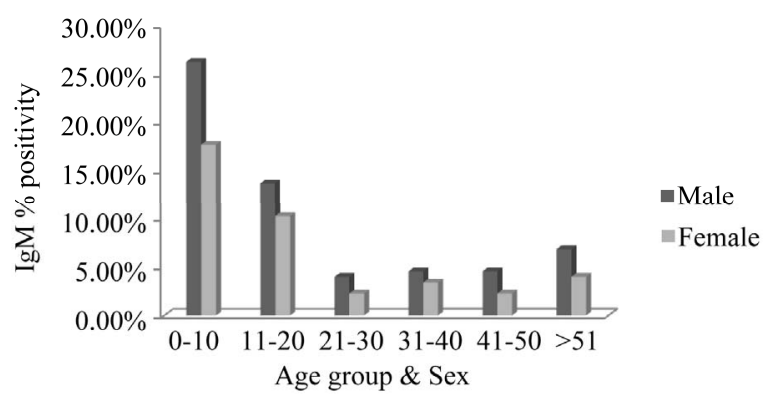

Figure 1. Age group \& Sex wise distribution of JE IgM positive cases from the year of 2005-2010.

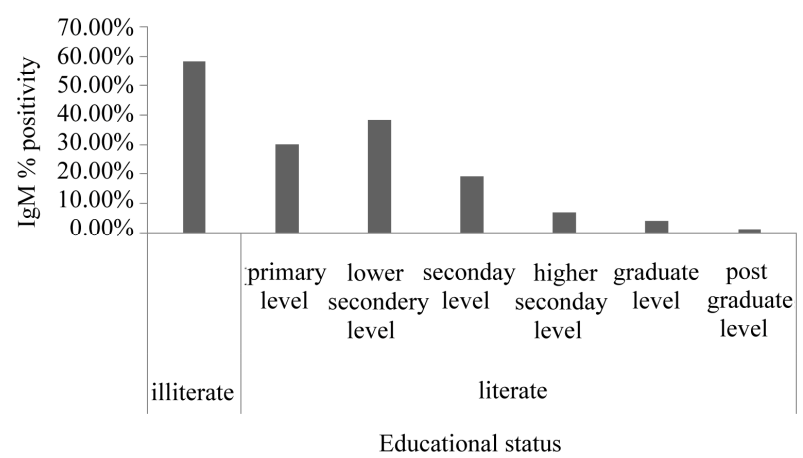

Figure 2. Educational status in respect to JE IgM positive cases from the year of 2005-2010.

As regards the financial status, 115 (65.7\%) JE IgM positive cases were from Low income group (income level $\leq 5000 /$ month) whereas only $60(34.3 \%)$ cases were detected from high income group (income level $>5000$ / month) (Table 2, Figure 3).

109 out of $175(62.3 \%)$ cases were found from the people living in the mud house, significantly higher in comparison to $66(37.7 \%)$ cases from the people living in the brick house (Table 2, Figure 3).

So far the location of the residence of the JE victimized people is concerned, 130 out of $175(74.3 \%)$ cases, i.e., the greater IgM positive cases were from the persons residing in houses near to the rice fields, the breeding sites of JE mosquito vector as well as adjacent to lakes/ ponds considered as the staging site of house hold fouls or birds and remaining $45(25.7 \%)$ cases were from the persons in the area far away from the rice fields/lakes/ ponds (Table 2, Figure 3).

As to the seasonal variations, most of the IgM positive 122 out of $175(69.7 \%)$ cases were seen in the monsoon and post-monsoon period (June to November) whereas only $53(30.3 \%)$ cases were found in the pre-monsoon period (January to May) (Table 2, Figure 3).

\section{DISCUSSION}

JE has become a major public health threat in West Bengal due to its complexity and lack of any specific

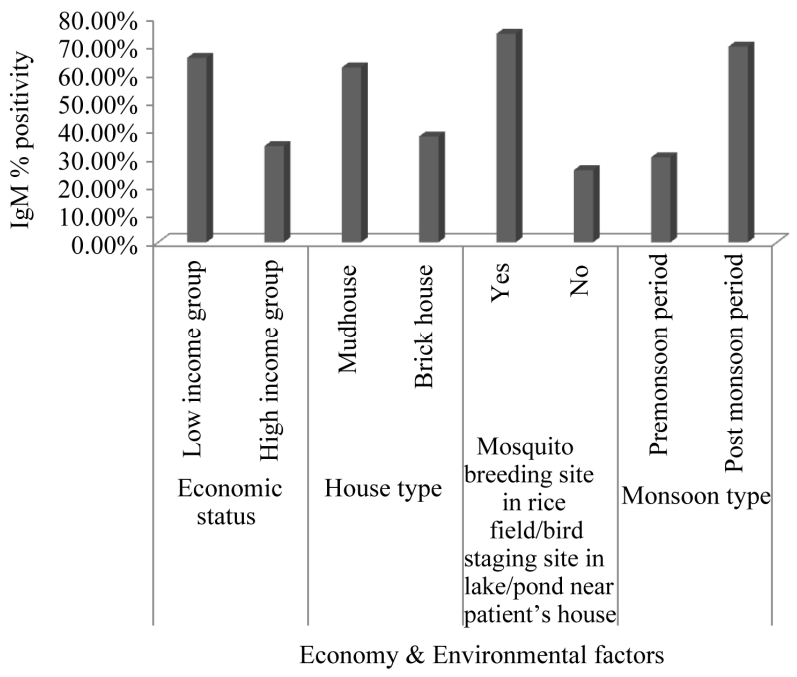

Figure 3. Economic status \& Environmental factors in respect to JE IgM positive cases from the year of 2005-2010.

treatment. Mainly, it is a rural disease and appeared in the form of large epidemics at intervals and has become endemic in many rural areas of West Bengal.

Effective vaccine against JEV is now available. Due to the widespread use of JE vaccine JE cases has been reduced in China, Korea, and Japan [29]. Although in some districts of West Bengal like Burdwan, Birbhum, Midnapore (W), Howrah and Hooghly, the vaccine was given by the State Health Department, Govt. of West Bengal [20], still sporadic cases are continuously being reported in every JE season.

In the present study, out of 648 samples (referred AES cases) tested, only $175(27.0 \%)$ samples were reactive against IgM antibody to JE and had the history of illness for $\geq 10$ days, indicative of active immune response at this stage of illness [30,31]. This observation amply proves the infection in the immediate past.

In our study, the total number of male individuals is significantly $(\mathrm{P}<0.01)$ higher $(60.0 \%)$ than that of females $(40.0 \%)$ amongst the JE IgM positive AES cases (Table 1, Figure 1). This observation is in tune with earlier observations in other studies [32-34].

Although, JE cases have been observed from all the age groups, highest numbers of JE positive cases have been recorded in the age group of 0 - 10 years (paediatric age group), followed by the age group of $11-20$ years (young and young adult age group) [35], in both male and female individuals (Table 1, Figure 1). The highest number of cases in the $0-10$ age group is possibly due to the lack of immunity in them [36]. Moreover, the male individuals in the age group of 15 - 20; usually take active part in crop field for the cultivation. The vector usually breeds in the stagnant water in the cultivation field and the majority from this age group gets exposed to the vector directly. 
Only a few cases were detected in the elderly age groups (Table 1, Figure 1). This Low number of JE IgM positive cases in the higher age group is possibly due to the development of immunity, either by sub clinical infections or due to the earlier vaccination, in them.

It is interestingly noted that during the study period, number of the IgM positive cases, i.e., 102 (58.3\%) out of 175 cases belonged to the illiterates and was found to be significantly $(\mathrm{P}<0.05)$ higher than the cases 73 $(41.7 \%)$ cases of the literate group of community (Table 2, Figure 2). In addition, amongst the literates, the lower educational level like primary, lower secondary and secondary constituted the maximum number $(87.7 \%)$ of the IgM positive cases while the higher educational level like higher secondary, graduate or post graduate professional group was least (12.3\%) affected (Table 3, Figure 2). It is worthy to mention that the illiterate rural people and literates with short of education were unaware of the disease and its preventive measures. Therefore, illiteracy or short of education is likely to play a great role to manifest the disease in this state.

The economy of West Bengal is mainly dependent on cultivation and the villagers have mostly taken up cultivation as the source of income. To raise the economic standard; poorer section of the community has accepted piggery and mini poultry as an accelerated source of income. Our study also reveals that majority of IgM positive cases, i.e., 115 out of $175(65.7 \%)$ belonged to the low income group (income level $\leq 5000 /$ month) and was to be found significantly $(\mathrm{P}<0.01)$ higher than that of the high income group (income level > 5000/month) comprising 60 (34.3\%) JE IgM positive cases (Table 2, Figure 3), mostly these low income group of rural people adopt cultivation as the main source of income. To raise their economic status; they usually take up piggery $[17,37]$ and mini-poultry in their own hut; commonly share the habitat with human population. It is worthy to mention that the stagnant water of paddy field affords a very congenial home for breeding of Culex mosquitoes [14] that act as a vector for JEV [4]. On the other hand, pigs, domestic birds like ducks, fouls which are known to be the favorable source for the maintenance of JEV in nature. Thus, this low income group community people become directly or indirectly exposed to JEV infection and this kind of data also satisfies that low economic status is one of the important risk factors in relation to JE incidences, corroborating with the earlier observation [38, 39].

According to our study, 109 number of IgM positive cases $(62.3 \%)$ originated from the mud houses was significantly $(\mathrm{P}<0.01)$ higher than that of 66 number of IgM positive cases $(37.7 \%)$ from the brick houses (Table 2, Figure 3). Our study pointed out that the house type (i.e., made up of mud or brick) is another contextual risk fac- tor in relation to the JE positive cases. This factor very much depends on the economic status. The persons living in brick houses belonged to high income group where as in case of low income group people living in unhygienic condition in mud houses with household crowding and lack of proper ventilation appear to be the risk factor for acquiring JE. This observation is in tune with earlier observations in other studies [38].

Previously, we have mentioned that the Culex mosquitoes are the vectors that breed in rice field and birds are the reservoir for JEV transmission. The residences of the incidental JE victimized people being in the close proximity to the breeding or staging site, i.e., rice fields, lakes or ponds for mosquitoes and marsh/migratory birds were likely to have a great influence on the disease manifestation. In this context, we came across a good number of $\operatorname{IgM}$ positive cases, i.e., 130 (74.3\%) belonging to those patients whose residents were much closer to the rice fields, lakes or ponds. These cases were significantly $(\mathrm{P}=0)$ higher than those of the 45 cases $(25.7 \%)$ of such victims whose residences were far away from the rice fields or lakes (Table 2, Figure 3).

In regard to the seasonal variations, monsoon and postmonsoon period make an influence to accelerate JE incidences. Most of the IgM positive cases, i.e., 122 out of $175(69.7 \%)$ cases found in the monsoon and post-monsoon period, were significantly $(\mathrm{P}<0.00001)$ higher whereas only $53(30.3 \%)$ cases were found in the pre- monsoon period (Table 2, Figure 3). It is worthwhile to mention that the monsoon and the post-monsoon period are the prime season for cultivation of paddy. At that time, all the paddy fields are covered with stagnant rain water for the need of the crops, which are preferred by the member of the Culex for breeding place [14] and mosquito density begins to rise with extensive paddy planting.

\section{CONCLUSIONS}

Now JE is the most common form of sporadic encephalitis in our state and should not be ruled out first before considering the other viral causes. In this paper, an attempt has been made to evaluate a great influence of socio-economic status and environmental factors on JE incidences in the state of West Bengal. Our study has clearly established the existence of JEV etiology in the sporadic JE incidences by performing antibody captured ELISA method against the JEV specific antigen.

JE risk was significantly associated with the rural residents living in close proximity to irrigated rice fields (preferred breeding place for vector mosquito of JE) and pig-rearing places. To avoid the risk of JE, these rural residents should take personal protection by using of mosquito repellant, insecticide-treated bed nets [40] and deet-permethrin soap [41], in order to reduce the mos- 
quito bite or vector exposure. In addition, the larvae of the vector mosquito should be controlled by some biological control strategies [42]. On the other hand, to overcome the risk of JE, rural residents should introduce either rearing of pigs in the modern farms separate from their housing [43] or rearing of cattle (considered as dead-end host with low viremia) [6] as a income source instead of pigs to reduce the chances of disease transmission [44]. Moreover, awareness programmes should be arranged to educate the illiterate rural residents about the disease and its horrible consequences so that they are eager to get them vaccinated against the disease.

Finally, based on this study, it is concluded that the socio-economic status and environmental conditions were statistically significant contextual risk factors for serologically diagnosed JE incidences in West Bengal. As no such study has yet been carried out, it constitutes a new report of this kind in the region.

\section{ACKNOWLEDGEMENTS}

We express sincere gratitude to all the staff members of ICMR Virus Unit, for their constant help and assistance to carry out the laboratory investigations and compilation of data. We also gratefully acknowledge the help we received from N.I.V, Pune for providing us the Elisa kit for the detection of IgM antibody to Japanese encephalitis virus. The enthusiastic help obtained from the doctors of the Medical Colleges and District Hospitals, for providing us the clinically suspected samples for this study, is gratefully acknowledged. We are indebted to the OfficerIn-Charge, ICMR Virus Unit, for allowing us to carry out the work in this Department. We received all sorts of financial help from the Department of Science and Technology, Govt. of West Bengal, India to carry out the work in the ICMR VIRUS UNIT, KOLKATA, INDIA.

\section{REFERENCES}

[1] Lindenbach, B.D. (2001) Flaviviridae: The viruses and their replication. In: Knipe, D.M. and Howley P.M., Eds., Fields Virology, Lippincott Williams and Wilkins, Philadelphia, 991-1041.

[2] Theodore, F.T. (1996) Effectiveness of live attenuated Japanese encephalitis vaccine (SA 14-14-2): A case-control study. The Lancet, 347, 1583-1586. doi:10.1016/S0140-6736(96)91075-2

[3] Tsai, T.F. (2000) New initiatives for the control of Japanese encephalitis by vaccination: Minutes of a WHO/CVI meeting, Bangkok, Thailand, 13-15 October 1998. Vaccine, 18, 1-25. doi:10.1016/S0264-410X(00)00037-2

[4] Geevarghese, G., Kanogia, P.C. and Mishra, A.C. (2004) Japanese encephalitis-Vector Biology. NIV Pune Year Book. Orient Longman Publication, Himayatnagar, 335- 356.

[5] Japanese Encephalstis. http://www.cfsph.iastate.edu/Factsheets/pdfs/japanese en cephalitis.pdf

[6] Reuben, R. and Gajanana, A. (1997) Japanese encephalitis in India. Indian Journal of Pediatrics, 64, 243-251.

\section{doi:10.1007/BF02752458}

[7] Diagana, M., Preux, P.M. and Dumas, M. (2007) Japanese encephalitis revisited. Journal of the Neurological Sciences, 262, 165-170. doi:10.1016/j.jns.2007.06.041

[8] Scherer, W.F., Kitaoka, M., Okuno, T. and Ogata, T. (1959) Ecologic studies of Japanese encephalitis virus in Japan. VII. Human infection. American Journal of Tropical Medicine and Hygiene, 8, 707-715.

[9] Smithburn, K.C., Kerr, J.A. and Gatne, P.B. (1954) Neutralising antibodies against certain viruses in the sera of residents of India. Journal of Immunology, 72, 248-251.

[10] Namachivayam, V. and Umayal, K. (1982) Proceedings of National Conference on Japanese Encephalitis. Indian Council of Medical Research, New Delhi, 30-33.

[11] Dhillon, G.P. and Raina, V.K. (2008) Epidemiology of Japanese encephalitis in context with Indian scenario. Journal of the Indian Medical Association, 106, 660-663.

[12] Kabilan, L., Rajendran, R., Arunachalam, N., Ramesh, S., Srinivasan, S. and Samuel, P.P. (2004) Japanese encephalitis in India: An overview. Indian Journal of Pediatrics, 71, 609-615. doi:10.1007/BF02724120

[13] Dutta, K., Rangarajan, P.N., Vrati. S. and Basu, A. (2010) Japanese encephalitis: Pathogenesis, prophylactics and therapeutics. Current Science, 98, 326-334.

[14] Chakravarty, S.K., Sarkar, J.K., Chakravarty, M.S., Mukherjee, M.K., Mukherjee, K.K. and Das, B.C. (1975) The first epidemic of Japanese encephalitis studied in IndiaVirological studies. Indian Journal of Medical Research, 63, 77-82.

[15] Ghosh, S.N., Rodrigues, F.M., Seth. G.P., Tongaonkar, S.S., Padbidri, V.S. and Gupta, N.P. (1975) Investigations on the outbreak of Japanese encephalitis in Burdwan district, West Bengal. Part II. Serological survey of human population. Indian Journal of Medical Research, 63, 14721477.

[16] Rodrigues, F.M., Ghosh, S.N., Banerjee, K., Chatterjee, A.K. and Gupta, N.P. (1975) A post-epidemic serological survey of humans in Bankura district, West Bengal, following the epidemic of Japanese encephalitis in 1973. Indian Journal of Medical Research, 63, 1478-1485.

[17] Rajagopalan, P.K. and Panicker, K.N. (1978) A note on the 1976 epidemic of Japanese encephalitis in Burdwan district, West Bengal. Indian Journal of Medical Research, 68, 3938.

[18] Banerjee, K., Sengupta, S.N., Dandawate, C.N., Tongaonkar, S.S. and Gupta, N.P. (1976) Virological and serological investigations of an epidemic of encephalitis which occurred at Bankura district, West Bengal. Indian Journal of Medical Research, 64, 121-130.

[19] Mukhopadhyay, B.B., Mukherjee, B., Bagchi, S.B., Chakraborty, M. and Mukherjee, K.K. (1990) An epidemiological investigation of Japanese encephalitis outbreak in Burdwan, District of west Bengal during 19871988. Indian Journal of Public Health, 34, 107-116.

[20] State Bureau of Health Intelligence (2009) Health on the March 2008-09. Director of Health Science, Goverment of West Bengal, p. 139.

[21] Burke, D.S. and Leake, C.J. (1986) Japanese encephalitis. 
In: Monath, T.P., Ed., The Arboviruses: Miology and Ecology, CRC, Boca Ruton, 3.

[22] Halstead, S.B. and Jacobson, J. (2003). Japanese encephalitis. Advances in Virus Research, 61, 103-138. doi:10.1016/S0065-3527(03)61003-1

[23] Latitude and Longitude of West Bengal. http://www.mapsofindia.com/lat_long/westbengal/westbe ngal.htm

[24] West Bengal. http://en.wikipedia.org/wiki/West_Bengal

[25] Census of India. http://censusindia.gov.in/

[26] Climate of West Bengal. http://www.webindia123.com/westbengal/land/climate.ht $\mathrm{m}$

[27] Borah, J., Dutta, P., Khan, S.A. and Mahanta, J. (2011) A comparison of clinical features of Japanese encephalitis virus infection in the adult and pediatric age group with Acute Encephalitis Syndrome. Journal of Clinical Virology, 52, 45-49. doi:10.1016/j.jcv.2011.06.001

[28] Khan, S.A., Dutta, P., Khan, A.M., Topno, R., Chowdhury, P., Borah, J. and Mahanta, J. (2011) Japanese encephalitis epidemiology in Arunachal Pradesh, a hilly state in northeast India. Asian Pacific Journal of Tropical Disease, 1, 119-122. doi:10.1016/S2222-1808(11)60050-9

[29] Kabilan, L. (2004) Control of Japanese encephalitis in India: A reality. Indian Journal of Pediatrics, 71, 707-712. doi:10.1007/BF02730659

[30] Lewthwaite, P., Shankar, M.V., Tio, P.H., Daly, J., Last, A. and Ravikumar, R. (2010) Evaluation of two commercially available ELISAs for the diagnosis of Japanese encephalitis applied to field samples. Tropical Medicine and International Health, 15, 811-818. doi:10.1111/j.1365-3156.2010.02537.x

[31] Solomon, T., Thao, L.T.T., Dung, N.M., Kneen, R., Hung, N.T. and Nisalak, A. (1998) Rapid diagnosis of Japanese encephalitis by using an immunoglobulin $\mathrm{M}$ dot enzyme immunoassay. Journal of Clinical Microbiology, 36, 20302034.

[32] Swami, R., Ratho, R.K., Mishra, B. and Singh, M.P. (2008) Usefulness of RT-PCR for the diagnosis of Japanese encephalitis in clinical samples. Scandinavian Journal of Infectious Diseases, 40, 815-820. doi:10.1080/00365540802227102

[33] L.-H., W., S.-H., Fu., H.-Yu, W., X.-F., L., J.-X., C. and H.-M., J. (2007) Japanese encephalitis outbreak, Yun- cheng, China, 2006. Emerging Infectious Disease, 13, 1123- 1124.

[34] Pant, S.D. (2009) Epidemiology of Japanese Encephalitis in Nepal. Journal of Nepal Paediatric Society, 29, 35-37. doi:10.3126/jnps.v29i1.1600

[35] Solomon, T. (2006) Control of Japanese encephalitiswithin our grasp? New England Journal of Medicine, 355, 869-871. doi:10.1056/NEJMp058263

[36] Chatterjee, S., Chattopadhyay, D., Bhattacharya, M.K. and Mukherjee, B. (2004) Serosurveillance for Japanese encephalitis in children in several districts of West Bengal, India. Acta Paediatrica, 93, 390-393. doi:10.1111/j.1651-2227.2004.tb02967.x

[37] Chatterjee, A.K. and Banerjee, K. (1975) Epidemiological studies on the encephalitis epidemic in Bankura. Indian Journal of Medical Research, 63, 1164-1177.

[38] Badari, V.S. (1985) A socio-economic study of Japanese encephalitis in Kolar district of Karnataka during 1981 Health and Population-Perspectives \& Issues, 8, 29-49.

[39] Luo, D., Ying, H., Yao, R., Song, J. and Wang, Z. (1995) Socio-economic status and micro-environmental factors in relation to the risk of Japanese encephalitis: A casecontrol study. Southeast Asian Journal of Tropical Medicine and Public Health, 26, 276-279.

[40] Luo, D., Zhang, K., Song, J., Yao, R., Huo, H., Liu, B., Li, Y. and Wang, Z. (1994) The protective effect of bed nets impregnated with pyrethroid insecticide and vaccination against Japanese encephalitis. Royal Society of Tropical Medicine and Hygiene, 88, 632-634. doi:10.1016/0035-9203(94)90201-1

[41] Mani, T.R., Reuben, R. and Akiyama, J. (1991) Field efficacy of "Mos-bar" mosquito repellent soap against vectors of bancroftian filariasis and Japanese encephalitis in Southern India. American Mosquito Control Association, 7, 565-568.

[42] Jennifer, K., Michael, F.M., Tobias, E.E., Robert, B., Marcel, T., Burton, H.S. and Jurg, U. (2005) Effect of irrigated rice agriculture on Japanese encephalitis, including challenges and opportunities for integrated vector management. Acta Tropica, 95, 40-57. doi:10.1016/j.actatropica.2005.04.012

[43] Nitatpattana, N., Audrey, D.P. and Ar Gouilh, M. (2008) Change in Japanese encephalitis virus distribution, Thailand. Emerging Infectious Diseases, 14, 1762-1765. doi:10.3201/eid1411.080542

[44] Vijayrani, H. and Gajanana A. (2000) Low rate of Japanese encephalitis infection in rural children in Thanjavur district (Tamil Nadu), an area with extensive cultivation. Indian Journal of Medical Research, 111, 212-214. 